\title{
Goitre, Cretinism and Iodine in South Asia: Historical Perspectives on a Continuing Scourge
}

\author{
M MILES*
}

\section{Introduction}

Sir Robert McCarrison's work on goitre, cretinism and the thyroid, begun in the western Himalayas in 1902, generated scores of scientific publications during the following thirtyfive years. ${ }^{1}$ Though that work is often considered the start of serious studies of goitre and cretinism in South Asia, in fact the use of iodine in goitre treatment in this region was noted by Commissioner David Scott at Rangpur in north-east India as early as $1825,{ }^{2}$ and was investigated in 1832 by Mountford Bramley at Kathmandu. ${ }^{3}$ Between Bramley's paper and McCarrison's commencement, over thirty journal papers appeared on South Asian goitre and its treatment. Many district reports and other studies referred to it. Indigenous treatments with iodine-bearing substances and animal thyroid extracts were also recorded. Yet 170 years after Scott's note, at least 10 million people in India, Nepal, Pakistan and Bangladesh still suffer mild to severe iodine-deficiency conditions, and over 150 million are considered at risk. ${ }^{4}$ In Bangladesh, iodine deficiency diseases have increased over recent decades, as a result of environmental degradation. ${ }^{5}$ Goitre and cretinism also continue to be significant problems in mountainous areas of China. ${ }^{6}$ The undoubted progress that has occurred in understanding goitre and cretinism and in knowledge of their treatment has yet to be universally applied. To do so is technically feasible in South Asia, though questions remain on epidemiology and there are serious doubts whether the socio-political will exists to tackle the problem. ${ }^{7}$ A "technical fix"

*M Miles, Commissary, Mental Health Centre, Peshawar. Address for correspondence: 4 Princethorpe Rd, Birmingham B29 5PX, England.

The author wishes to acknowledge useful comments on earlier drafts, from J Newmark, A G Stewart, P O D Pharoah and K G Zysk.

\footnotetext{
${ }^{1}$ See bibliography in Hugh M Sinclair (ed.), The work of Sir Robert McCarrison, London, Faber \& Faber, 1953, pp. 307-12. Foundation studies were: Robert McCarrison, 'Observations on endemic goitre in the Chitral and Gilgit valleys', Lancet, 1906, i: 1110-11; idem, 'Observations on endemic cretinism in the Chitral and Gilgit valleys', ibid., 1908, ii: $1275-80$.

2 'Extract of a letter from D. Scott Esq. Commissioner, Rungpore District, communicated by G. Swinton, etc.', Trans. med. Physical Soc., Calcutta, 1825, 1: 367. Senior administrator George
}

Swinton had been Scott's fellow student at Fort William College, 1802-1804.

${ }^{3}$ Mountford J Bramley, 'Some account of the bronchocele, or goitre of Nipal, and of the Cis, and Trans-Himalayan regions', Trans. med. Physical Soc., Calcutta, 1833, 6: 181-264.

${ }^{4}$ R S Pandey and Lal Advani, Perspectives in disability and rehabilitation, New Delhi, Vikas, 1995, p. 33.

${ }^{5}$ H K M Yusuf, S Quazi, M N Islam, T Hoque, K M Rahman, M Mohiduzzaman, et al., 'Current status of iodine-deficiency disorders in Bangladesh', Lancet, 1994, i: 1367-8.

6 James S Lawson and Vivian Lin, 'Health status differentials in the People's Republic of China', Am. J. publ. Hlth, 1994, 84: 737-41.

${ }^{7}$ The national goitre control programme. A blueprint for its intensification, Nutrition Foundation of India, 1983, pp. 10-11, 55-6. 


\section{Miles}

alone cannot provide a solution. Social processes are involved, demanding political determination, and skill in community education. There are perspectives to be gained on these social processes from historical studies.

\section{Ancient and Medieval Evidence}

The major medical text of Indian antiquity, Sushruta samhita, ${ }^{8}$ has much to say about head and neck diseases. ${ }^{9}$ The relevant section Nidanasthanam, chapter XI, gives a detailed description of four types of goitre, and concludes that "A pendent swelling whether large or small and occurring about the region of the throat and resembling the scrotum in shape is called a Gala-Ganda." 10 Sushruta recommended vapour fomentations, poultices and some internal potions; also the excision of the fatty contents, or cautery. ${ }^{11}$ However, a goitre of more than a year's standing was considered incurable. ${ }^{12}$

Seaweeds were used in goitre treatment in China, perhaps as early as the third millennium BC. ${ }^{13}$ Numerous Chinese sources exist on goitre from the fourth century BC onwards, with marine plants identified in the first century BC as a remedy, and the use of animal thyroid extracts in the seventh century CE. ${ }^{14}$ Joseph Needham speculated that the use in twelfth-century Europe of iodine-bearing plants derived from Chinese knowledge passed on between seafarers "in port somewhere in the Indo-Iranian seas". ${ }^{15}$ Some of this knowledge was probably also available in Indian antiquity, though traces of it are not apparent until the later European period. ${ }^{16}$ Use of seaweed or animal thyroid is found neither in Thomas Wise's description of Hindu medicine in $1845,{ }^{17}$ nor in K N N Sen Gupta's more detailed view of goitre in Ayurveda. ${ }^{18}$ Such treatments do not appear among the Nepali vaids' practices noted by Surgeon Wright $(1867) ;{ }^{19}$ nor in Walter Lawrence's

${ }^{8}$ Sanskrit terms and Asian place names are quoted from various sources in different periods. Transliteration and spelling are not systematized.

${ }^{9}$ Ranes C Chakravorty, 'Head and neck diseases in an ancient Indian surgical text', Med. Hist., 1971, 15: 393-6. Compilation of the Sushruta samhita may have begun as early as $200 \mathrm{BC}$. It is usually dated two or three centuries later.

${ }^{10} \mathrm{~K}$ K L Bhishagratna, An English translation of the Sushruta samhita, 3 vols, Varanasi, Chowkhamba Sanskrit Series Office, 1981, vol. 2, p. 78. Modern interpretation of symptoms listed by Sushruta is given by G D Singhal, L M Singh and K P Singh, Diagnostic considerations in ancient Indian surgery, Allahabad, Singhal, 1972, p. 171.

${ }^{11}$ G D Singhal and L M Singh, Operative considerations in ancient Indian surgery, Varanasi, Singhal Publications, 1982, pp. 352-4.

${ }_{12}$ Bhishagratna, op. cit., note 10 above, p. 78.

13 Basil S Hetzel, The story of iodine deficiency, Oxford University Press, 1989, p. 4. Victor C Medvei, A history of endocrinology, Lancaster, MTP Press, 1982, pp. 15-18, 86, 189. Saburo Miyasita, 'An historical analysis of Chinese drugs in the treatment of hormonal diseases, goitre and diabetes mellitus', Am. J. Chinese Med., 1980, 8: 17-25.
$14 \mathrm{~J}$ Needham, Clerks and craftsmen in China and the west, Cambridge University Press, 1970, pp. 298-302. One Chinese official, noted in the fourth century BC, did not seek these remedies: "Pitcherneck with the big goitre advised Duke Huan of Ch'i; the Duke was so pleased with him that when he looked at normal men their necks were too scrawny." Chuang-tzu. The seven inner chapters, transl. A C Graham, London, Allen \& Unwin, 1981, p. 80 .

15 Needham, ibid., p. 300.

${ }^{16}$ Early Sino-Indian medical exchange through Buddhist missionaries is outlined by Paul Unschuld, 'The Chinese reception of Indian medicine in the first millennium A.D.', Bull. Hist. Med., 1979, 53: 329-45. Knowledge of seaweed treatment might indeed have reached India several times, only to disappear across centuries.

${ }^{17} \mathrm{~T}$ A Wise, Commentary on the Hindu system of medicine, Calcutta, Thacker, Ostell and Lepage, 1845, pp. 313-15.

${ }^{18} \mathrm{~K}$ N N Sen Gupta, The Ayurvedic system of medicine, rev. ed., 3 vols., Calcutta, Chatterjee, 1909, vol. 1, pp. 280-4; vol. 2, pp. 536-9.

19 D Wright, 'A few notes from Nepaul', Indian med. Gaz., 1867, 2: 194-6, p. 196. 


\section{Goitre, Cretinism and Iodine in South Asia}

list of standard medicines in Kashmir, where goitre was common and medicines were regularly imported from China. ${ }^{20}$ However, goitre treatment by indigenous practitioners in the nineteenth century, using the seaweed Laminaria saccharina, will be discussed below.

Kenneth Zysk gives details, from early Buddhist literature, of various swellings (ganda) and their treatments, but galaganda is absent. ${ }^{21}$ Galaganda does appear in a list of thirtytwo medical conditions or disabilities, the sufferers from which were barred from ordination as monks, according to the ancient Buddhist Book of Discipline. ${ }^{22}$ However, a great range existed of vocabulary and deformations of words concerning the neck, windpipe, swelling, tumour or goitre, so lexical evidence is hardly conclusive. ${ }^{23}$ Some of the terms blend with words for humpback and dumb (e.g. gadula $<->$ ganda $<->$ gunga $<->$ gheggha; cf. Greek ganglion = tumour), but these are part of a profusion of IndoAryan "defect" words noted by the lexicographer Ralph Turner. ${ }^{24}$ They do not necessarily imply an early association of goitre with cretinism. In later medicine linked to Buddhism, as in modern Tibet, various goitres were differentiated, and treated by diet, medicine or cautery. ${ }^{25} \mathrm{~W}$ R Morse, a pioneer of medical anthropology, learnt from Tibetan informants that "The gullet of animals is used as a cure" for the common problem of goitre; also "dried olives from India". ${ }^{26}$ Goitre may be indicated in the swollen neck of an attendant in a Buddha frieze from the Gandhara region in the second or third century CE. The man's expression appears stupid compared with others sculpted in the frieze, perhaps suggesting cretinism; and he may have been exophthalmic. ${ }^{27}$ Centuries passed before a surviving artistic representation clearly connected goitre and cretinism in European iconography, as demonstrated by the surgeon and historian Franz Merke in his substantial study of goitre. $^{28}$

Between antiquity and the modern period, there are vast gaps. Merke noted that "Long stretches in the development of our knowledge of goitre are plunged in darkness", even in Europe where his studies were focused. ${ }^{29}$ There could, however, be a curious connection between goitre and European notions of India. Some of the tales of "monsters in the East",

${ }^{20}$ W R Lawrence, The valley of Kashmir, London, Henry Frowde, 1895, pp. 74-7.

${ }^{21}$ Kenneth G Zysk, Asceticism and healing in ancient India. Medicine in the Buddhist monastery, Delhi, Oxford University Press, 1991, pp. 98-101.

${ }^{22}$ The Vinaya Pitakam Vol. I. The Mahâvagga, edited by Hermann Oldenberg, London, Luzac \& Company for the Pali Text Society, 1964, p. 91.

${ }^{23}$ Sir Ralph Turner, A comparative dictionary of the Indo-Aryan languages, London, Oxford University Press, 1966, pp. 213, 218, 223, 244, etc.

24 Ibid., Introduction, p. $x$.

${ }^{25}$ Gerard N Burrow and Jeffrey Hopkins, 'Goiter in Tibetan medicine', Yale J. biol. Med., 1978, 51: 441-7, pp. 444-5.

26 W R Morse, 'Tibetan medicine', J. W. China Border Res. Soc., 1929, 3: 114-33, p. 128. At Penang, M E Scriven, 'Goitre treated successfully with the thyroid extract', Indian med. Rec., 1902, 22: $120-1$, instructed a patient to mince up sheeps' thyroids "nicely with pepper and salt to taste" (p. 120), but saw no benefit over seven weeks. He then prescribed "thyroid extract tabloids" successfully (p. 120). Scriven commented sceptically on experiences in the $1880 \mathrm{~s}$, "when the biniodide of mercury pendulum was in full swing" (p. 121).

${ }^{27}$ Baruch S Blumberg, 'Goiter in Gandhara. A representation in a second to third century $\mathrm{AD}$ frieze', J. Am. med. Ass., 1964, 189: 1008-12. Exophthalmic goitre was, however, considered very rare in India by J Fayrer, 'On bronchocele', Lancet, 1874 , ii: $580-1,617-18$, p. 581 ; and by H Stott, B B Bhatia, R S Lal and K C Rai, 'The distribution and cause of endemic goitre in the United Provinces', Indian J. med. Res., 1931, 18: 1059-85, p. 1064.

${ }^{28} \mathrm{~F}$ Merke, History and iconography of endemic goitre and cretinism, transl. D Q Stephenson, Bern, Huber, 1984, p. 266. An earlier literary link, which escaped Merke, appeared in a fifth-century CE Irish legal text listing twelve varieties of fool. One is the boicmell "under whose neck are the soft lumps"presumably a goitrous fool. See R M Smith, 'The advice to Doidin', Ériu, 1932, 11: 66-85.

${ }^{29}$ Merke, op. cit., note 28 above, p. 2. 


\section{Miles}

popular in Europe for nearly two thousand years, may have arisen from early travellers' encounters with goitrous Indian cretins. ${ }^{30}$ Late eighteenth-century descriptions of Alpine cretins used such terms as "facies ipsis vix humana" (their appearance is scarcely human), "non multo meliores brutis animalibus" (little better than senseless beasts), ${ }^{31}$ and "l'individu, car je ne saurois le nommer un homme" (the being, whom I could hardly call human). ${ }^{32}$ The effect of walking into a village from which all able-bodied people were absent working in the fields was described by the physicist Horace-Bénédicte de Saussure. The only people he met were grossly deformed cretins, arousing the terrifying impression, even in a hard-boiled scientist, that the villagers had been transformed by an evil spirit into monstrous caricatures of humanity. ${ }^{33}$ Travellers having a similar fright in India, centuries earlier, could have started the circulation and subsequent embroidery of some monster myths. Merke noted that the first clear description of Alpine cretins, ${ }^{34}$ by Jacques de Vitry, occurs precisely at the end of a catalogue of Indian monsters. ${ }^{35}$ The origins of some elfish legends may similarly be linked to an underlying Himalayan reality. ${ }^{36}$

\section{The European Period}

Abul Fazl, in his detailed record of Akbar's government and times, $c$. 1590, noted that people in Bihar who drank of the river Gandak "suffer a swelling in the throat, which gradually increases, especially in young children, to the size of a cocoanut." 37 Casual mention of goitres in the Himalayan region appeared even earlier in travellers' reports, such as that of Marco Polo in the thirteenth century, ${ }^{38}$ but only in the late eighteenth century do such accounts provide a more carefully observed picture. The celebrated historian of Bengal, Ghulam Husain Salim, writing of the Purniah region c. 1788, commented that "Tumours of the throat in men and women generally, as well as in wild beasts and birds" were common. ${ }^{39}$ Captain Turner's report, of an embassy to greet an infant Lama in Tibet in 1783, gave a short catalogue of the known goitrous regions in the Himalayas, probably the earliest in the modern period. On aetiology, Turner was more cautious than many writers: "This wen . . . in Europe is called Goitre, and has the effect, or rather is accompanied with the effect, arising from the same cause, of debilitating both the bodies and the minds of those who are effected with it." 40 A report of the same period by surgeon Robert Saunders was later incorporated into that of Turner, and included an

\footnotetext{
${ }^{30}$ Rudolf Wittkower, 'Marvels of the East. A study in the history of monsters', $J$. Warburg and Courtauld Inst., 1942, 5: 159-97. Wittkower conceded that "Sometimes real observation may have been at the bottom of the story" (p. 164).

${ }^{31}$ Albrecht von Haller, Elementa physiologia corporis humani, 8 vols, Lausanne, Grasset, 1763, vol. 5 , bk 17 , p. 570 .

${ }^{32}$ Horace-Bénédicte de Saussure, Voyages dans les Alpes, 4 vols, Neuchâtel, Fauche-Borel, 1803, vol. 4, pp. 127, 264.

${ }^{33}$ Ibid., pp. 126-7.

${ }^{34}$ Merke, op. cit., note 28 above, pp. 132-5.

${ }^{35}$ See Jacques Bongars (ed.), Gesta dei per Francos, sive orientalium expeditionum et regni
}

Francorum hierosolymitani historia, Hanover, 1611, pp. 1112-13.

36 Claude Lecouteux, Les nains et les elfes au moyen âge, Paris, Editions Imago, 1988, p. 21.

${ }^{37}$ Abul Fazl, Aín i Akbarí, 3 vols, Calcutta, Asiatic Society of Bengal, 1891, vol. 2, transl. H S Jarrett, p. 150.

${ }^{38}$ The travels of Marco Polo the Venetian, Everyman's library No. 306, London, Dent, 1908, reprinted 1927, p. 95.

${ }^{39}$ Ghulam Husain Salim, Riyazu-s-Salatin, transl. Maulavi Abdus Salam, Calcutta, 1902-1904, p. 38.

${ }^{40}$ Samuel Turner, An account of an embassy to the court of the Teshoo Lama in Tibet, 2nd ed., London, Bulmer and Nicol, 1806, pp. 86-7. 
account of goitre. ${ }^{41}$ Saunders found one in six people goitrous in Rangpur district and neighbouring Bhutan, ${ }^{42}$ a similar proportion to that estimated by Dr Gillan during his travels in Chinese Tartary as part of the Macartney embassy. ${ }^{43}$ Eighty years later, goitre was still "common everywhere in Thibet", according to the commercial prospector Thomas Cooper, who visited one village where "All the people, without a single exception, from the old grey-headed men to the youngest children, suffered from goître."44

Colonel Kirkpatrick, visiting Nepal in 1793, noted "the guttural tumours known in Hindostan by the name of Ghaigha, and in Nepaul by that of Gânoo". 45 The Nepalis suspected the water supply, but were puzzled by the fact that the water of the river Bhagmutty seemed to produce goitres in some locations but not others. The goitres in Kaurigong and Deopatun were therefore "gravely believed by many of the inhabitants to be an effect of imagination in their pregnant women, who, it seems, are constantly exposed to the disgusting sight presented in the protuberant pouches of the innumerable monkies". ${ }^{46}$ McCarrison would later find Chitrali mothers attributing to their continuous exposure to local cretins the fact that they gave birth to cretinous babies. ${ }^{47}$ However, Surgeon Wright in his article on Nepal pointed out that the belief recorded by Kirkpatrick failed to account for there being few infants with goitre. ${ }^{48}$ The tireless surveyor and acute medical observer Francis Buchanan, reporting on Bhagalpur in 1810-11, contrasted the prevalence of goitre on either side of the Ganges, and speculated about its cause, but could not reach a theory that suited his observations. ${ }^{49}$ Mir Izzet Ullah, on a reconnaissance trip for the traveller William Moorcroft, recorded goitre at Leh and Yarkand in 1812. ${ }^{50}$ Later, Moorcroft and George Trebeck noted goitre in Ladakh around 1820. They found no local explanation for it, still less a reason "why the complaint is almost confined to the women, scarcely a woman being free of it, whilst it is rare amongst men." 51 George Traill, an outstanding "benevolent patriarch" type of Commissioner who by the late 1820s was

${ }^{41} \mathbf{R}$ Saunders, 'Some account of the vegetable and mineral productions of Boutan and Thibet', Phil. Trans. R. Soc., 1789, 79: 79-111.

42 Ibid., p. 99.

${ }^{43}$ Sir George Staunton, An authentic account of an embassy from the King of Great Britain to the Emperor of China, etc., 2 vols, London, W Bulmer for G Nicol, 1797, vol. 2, p. 202. The same proportion was found a century later at Mussoorie by W P Heher, 'Acute bronchocele', Indian med. Gaz., 1881, 16: 81-2.

44 Thomas T Cooper, Travels of a pioneer of commerce in pigtail and petticoats, London, John Murray, 1871, p. 304.

45 William Kirkpatrick, An account of the kingdom of Nepaul, London, Miller, 1811, pp. 173-4. 46 Ibid.

${ }^{47}$ McCarrison, op. cit., note 1 above, 1908, p. 1277. Thomas Schlich, 'Changing disease identities: cretinism, politics and surgery (1844-1892)', Med. Hist., 1994, 38: 421-43, on pp. 428-9 cites sources from the 1840 s in Germany, where a similar theme occurred frequently.

\author{
48 Wright, op. cit., note 19 above, p. 195. \\ ${ }^{49} \mathrm{~F}$ Buchanan, An account of the district of \\ Bhagalpur in 1810-11, Patna, Bihar \& Orissa \\ Research Society, 1939, pp. 174-5. Buchanan's \\ district reports on Purnea, Bihar and Patna, and \\ Shahabad, all mention that goitres were common. \\ Idem, An account of the district of Purnea in \\ 1809-10, same publisher, 1928, p. 124. Idem, An \\ account of the district of Shahabad in 1809-10, same \\ publisher, 1934, p. 156. Idem, An account of the \\ district of Bihar and Patna in 1811-12, same \\ publisher, no date, p. 273. In the latter report, on \\ p. 274, Buchanan gave the first colonial description \\ of another common north Indian disabling condition, \\ lathyrism, later linked with dietary deficiency. \\ ${ }^{50}$ Mir Izzet Ullah, 'Travels beyond the \\ Himalaya', J. R. Asiat. Soc., 1843, 7: 283-342, \\ pp. $289,303$. \\ ${ }^{51}$ William Moorcroft and George Trebeck, \\ Travels in the Himalayan provinces of Hindustan and \\ the Panjab ... from 1819 to 1825 , London, John \\ Murray, 1841, reprinted at Karachi, Oxford \\ University Press, 1979, vol. 2, pp. 25-6.
}




\section{Miles}

known as "King of Kumaon", stated that some European women and children in Kumaon had acquired goitres, but no European men. ${ }^{52}$ Amir, a Cashmiro-Bhotiah interpreter, reported that the waters of a certain river in the kingdom of Lhasa conferred freedom from goitres. ${ }^{53}$ Captain Skinner found plentiful goitres in adults, when walking in the Himalayas, but none in children. ${ }^{54}$ However, he also mentioned "deaf and dumb children" in one mountain village, whose parents "call them idiots, and say they are good for nothing."55

After Saunders' 1789 account, the next goitre reports by physicians appeared between 1826 and 1831 in surveys of medical topography. Peter Breton, Superintendent of the Native Medical Institution, Calcutta, mentioned goitre among the main diseases of Indians in Ramghur and nearby regions "which do not affect Europeans in India". ${ }^{6}$ James Evans, in Tirhoot district, wrote of "bronchocele, with the physiology and pathology of which we are but little, if at all acquainted." He noted that many people with bronchocele were "also subject to aberration of mind", and that the goitres could be so large as to threaten suffocation during vigorous movement; also that European children, but seldom adults, were liable to develop goitres. ${ }^{57}$ Discussing goitre cases seen in Lower Assam, John Leslie commented that "iodine, in the form of tincture and ointment of Hydriodate of Potass, was successfully exhibited." 58 Iodine was being used to treat all sorts of diseases in Europe, ${ }^{59}$ and this enthusiasm spread to India. Another Calcutta physician, William Twining, noted that its efficacy with goitres had led some doctors unwisely to try it for chronic liver conditions. ${ }^{60}$

Remarkably, the first clear report of iodine treatment for South Asian goitre appeared as early as 1825 in an extract from a letter by another "benevolent patriarch", Commissioner David Scott, at Rangpur. Without benefit of an ethics committee, Scott had cheerfully been experimenting on local people with treatments picked up through his assiduous reading of medical journals:

My patients are all alive and well, and have not suffered any inconvenience from the use of the Iodine, besides occasional squeamishness after taking their dose. The first case was that of Gujraj, aged 24. He had had the Ghig (Goitre) for nine years, and his neck was so much enlarged as to impede respiration, and induce a sense of suffocation, on his running or taking any violent exercise. This inconvenience has now entirely ceased, and the enlargement of the throat is reduced to about one fourth of its original size. He has taken, not very regularly, for almost two months, twenty drops twice a day of a solution of ten grains of Iodine in two oz. of spirits of wine. Several slighter and

\footnotetext{
52 George W Traill, 'Statistical sketch of Kamaon', Asiatic Researches, 1828, 16: 137-234, pp. 215-16. See also L S S O'Malley, The Indian Civil Service: 1601-1930, London, John Murray, 1931 , p. 54.

53 Amir, communicated by Bryan Houghton Hodgson, 'Route from Cathmandu, in Nepal, to Tāzedo, on the Chinese frontier', Asiatic Researches, 1832, 17: 513-34, p. 533.

54 Thomas Skinner, Excursions in India, 2nd ed., London, Bentley, 1833, vol. 1, p. 305.

55 Ibid., vol. 2, pp. 36-8. By contrast, Staunton, op. cit., note 43 above, p. 203, found that goitrous idiots were "considered in some degree sacred" and were cherished by their families.
}

\footnotetext{
${ }^{56} \mathrm{P}$ Breton, 'Medical topography of the districts of Ramghur, Chota Nagpore, Sirgooja, and Sumbhulpore', Trans. med. Physical Soc., Calcutta, 1830, 2: $234-46$.

$57 \mathrm{~J}$ Evans, 'Observations on the medical topography of Tirhoot', Trans. med. Physical Soc., Calcutta, 1829, 4: 241-6, pp. 245-6.

$58 \mathrm{~J}$ Leslie, 'A sketch of the medical topography of Gowhattee', Trans. med. Physical Soc., Calcutta, 1833, 6: 33-63, p. 57.

59 A L J Bayle, Bibliothèque de Thérapeutique, 4 vols, Paris, Gabon, 1828-37, vol. 1, pp. 193-7.

${ }^{60} \mathrm{~W}$ Twining, 'Observations on some of the effects of iodine', Trans. med. Physical Soc., Calcutta, 1833, 6: 386-91.
} 


\section{Goitre, Cretinism and Iodine in South Asia}

more recent cases have been almost entirely cured in the course of ten or fourteen days. I have not tried the Hydriodate, as I have found the tincture to answer so well, and am not quite sure how the other is administered. ${ }^{61}$

Buried among the appendices to the inaugural volume of Transactions of the Medical and Physical Society of Calcutta, this note was cited by no subsequent writer-perhaps because its index heading gives no clue to the contents. Scott's powers of medical observation would hardly have been questioned by his contemporaries, among whom he was known as a tireless polymath.

The first substantial medical study on goitre in South Asia was Bramley's, read in November 1832 to the Medical and Physical Society of Calcutta, ${ }^{62}$ which "occupied a good deal of the attention of the Society". ${ }^{63}$ Much of the research was done in Nepal, but Bramley extended his enquiries from "the plains of Hindoostan . . . to the north-western frontier and north-eastern confines of the Chinese empire". ${ }^{64}$ Bramley had spent eighteen months in Switzerland in his teens. He was studying in Geneva in $1818,{ }^{65}$ i.e. after the isolation of iodine from seaweed by Bernard Courtois in Paris in 1811 (publicly presented in 1813), ${ }^{66}$ and before the discovery in 1819 by Coindet, in Geneva, of the efficacy of iodine in the treatment of goitre, published in $1820 .{ }^{67}$ Coindet himself attributed to Arnold of Villanova (d. 1311) the introduction of calcined sponge, which had "hitherto formed the basis of all those remedies which have had any success in goitre."68 Coindet's contribution had been to guess that the newly-discovered iodine was the effective ingredient in burnt sponge, and to test the hypothesis. His results appeared in English in the same year, ${ }^{69}$ and James Johnson's translation of three of his papers appeared in $1821 .{ }^{70}$ In that year, the London physician Shuckburgh Roots switched from burnt sponge treatment to iodine ointment for a case he was treating in England, after hearing a letter from Coindet read out to the Medico-Chirurgical Society. ${ }^{71}$ Edward Barlow, a physician at Bath, cited Johnson's translation when reporting

${ }^{61}$ Scott, op. cit., note 2 above. Adam White, Memoir of the late David Scott, Esq., edited and annotated by Archibald Watson, Calcutta, 1832, p. 53. See also Nirode K Barooah, David Scott in north-east India 1802-1831. A study in British paternalism, New Delhi, Munshiram Manoharlal, 1970.

62 Bramley, op. cit, note 3 above.

${ }^{63}$ A Campbell, 'Case of laryngitis, complicated with bronchocele', Trans. med. Physical Soc., Calcutta, 1836, 8 (1): xviii-xix.

${ }^{64}$ Bramley, op. cit., note 3 above, p. 182.

65 Ibid., pp. 181, 204. Mountford Joseph Bramley (1803-37) gained his MRCS in 1825. Appointed Assistant Surgeon, Bengal, in August 1829, he was posted to Nepal where he made his study of goitre. He became the first Principal of the Medical College, Calcutta, in 1835. (See D G Crawford, Roll of the Indian Medical Service 1615-1930, London, Thacker, 1930.)

${ }^{66}$ Bernard Courtois, Session of the Académie des Sciences, 6 December 1813, report by $\mathrm{N}$ Clément and J L Gay-Lussac, cited by Merke, op. cit., note 28 above, p. 9.

${ }^{67}$ [J-F] Coindet, 'Découverte d'un nouveau remède contre le goître', Ann. Chim. Phys., 1820, 15: 49-59. Some later commentators, confusing different members of the Coindet family, or following Johnson (see note 68 below), have given various initials to this paper's author, who was in fact Dr Jean-François Coindet, father of Dr Jean-Charles Walker Coindet (known as Charles W Coindet) and of Jean-JacquesFrancois Coindet (known as John Coindet).

68 James R Johnson, Observations on the remarkable effects of iodine in bronchocele and scrophula. Being a translation of three memoirs published by J. R. Coindet, M.D. of Geneva, London, Longman, Hurst, et al., 1821, p. 8.

69 [J-F] Coindet, 'Observations on the use of iodine as a remedy for bronchocele', London med. phys. J., 1820, 44: 486-9.

70 Johnson, op. cit., note 68 above.

${ }^{71}$ H S Roots, 'A case of bronchocele', Lancet, 9 Nov. 1823: 201-3. 


\section{Miles}

success with iodine treatment in 1824, having previously used "bark and burnt sponge" with mixed results. ${ }^{72}$ By then, Coindet's work was presumably becoming known in India. ${ }^{73}$

Bramley, like most subsequent observers, ${ }^{74}$ was struck by the sharp variation in goitre prevalence among Himalayan populations living in close proximity, for example, from around 2 per cent of one village to more than 30 per cent of the next in the same valley and without any obvious factor differentiating the two. ${ }^{75}$ Bramley was not easily misled by casual reports. Like Moorcroft and Trebeck, he heard that in some places "all the women have it, but very seldom the men". ${ }^{76}$ Yet he found that "upon examining the necks [of the men who had given this information] the thyroid gland was, without an exception, more or less enlarged", though this was not immediately obvious because their neck muscles were highly developed through carrying large loads attached with head bands. ${ }^{77}$ "More or less enlarged" is hardly precise; yet Bramley did measure necks. He described diets, had water sources analysed, tabulated climatic variations, and accumulated 116 case histories, from which he presented those illustrating salient points. Initially Bramley administered iodine both externally and internally. He soon decided against internal use, and thereafter "the sum total of remedies employed by me, consisted of iodine ointment, keeping the neck constantly covered, and simple friction, over the diseased growth, with common lard." 78 He reported 57 patients "discharged cured", while 48 gained benefit but failed to persevere with treatment. Six "obtained only partial relief after a trial of two months, and five were wholly unsuccessful". ${ }^{79}$ In the latter, the goitres were longstanding.

Thus, within a few years of the publication of Coindet's findings in Paris and Geneva, the successful treatment of goitre with iodine was proceeding in India, and, within a further decade, a systematic report was published. Cretinism, however, was much less evident. While noting Staunton's account from Chinese Tartary, in which goitre was associated with "much weakened" minds, even to the extent of "absolute idiocy", 80 Bramley stated that he himself saw no cretinism, nor "any thing approaching to it". ${ }^{81}$ Nor did Frederick Brett see it at Almorah, ${ }^{82}$ though he thought that one in ten of the population had goitres. After Bramley's comprehensive groundwork, John McClelland soon followed with a series of deductions from studies of goitre in Kumaon by which he excluded from

\footnotetext{
${ }^{72}$ E Barlow, 'A case of bronchocele successfully treated by iodine', Edinb. med. surg. J., 1824, 21 : 337-8.

${ }^{73}$ Iodine treatment for goitre might also have reached India via the experiments of Prout and Elliotson, 1816-19, and the latter's clinical teaching in London. See William Prout, Chemistry, meteorology, and the function of digestion, London, Pickering, 1834, fn. pp. 113-14; and 'Obituary: John Elliotson, M.D. Cantab., F.R.S.', Lancet, 1868, ii: 203-4. Adverse reports of iodine overdosing and hyperthyroidism which beset Coindet within months of his first publication, might have made Prout and Elliotson reticent about their priority in this field. A recent search in St Thomas's Hospital archives has yet to find any evidence supporting Prout's claim of iodine use in treating goitre there before 1820 .

${ }^{74}$ See, e.g., reflections by Alex G Stewart, 'For debate: drifting continents and endemic goitre in northern Pakistan', Br. med. J., 1990, i: 1507-12.
}

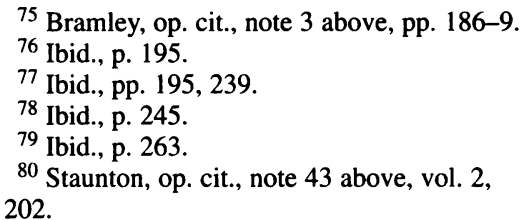
p. 202.

${ }^{81}$ Bramley, op. cit., note 3 above, p. 206.

Cretinism was much more evident to a later Presidency Surgeon in Nepal: John Brown, 'Note on the prevalence of goitre', Indian Ann. med. Sci., 1859, 6: 176-7. John M'Clelland further noted that Bramley's observations were limited by his being "attached to the court of a native state": Sketch of the medical topography, or climate and soils, of Bengal and the N. W. Provinces, London, Churchill, 1859, pp. 105-6.

82 Frederick H Brett, A practical essay on some of the principal surgical diseases of India, Calcutta, Thacker, 1840, p. 113. 


\section{Goitre, Cretinism and Iodine in South Asia}

the possible aetiology such factors as temperature, altitude, surface irregularities of the earth, and heredity. ${ }^{83}$ Like Evans and Bramley, McClelland was struck by the observation that one village with little goitre might be surrounded by villages where it was common, and vice versa. Later, he was careful to note that there were villages where goitres were common yet there were no cretins, while in another five villages with 138 inhabitants, "76 have goitre, and 42 are cretins"; but cretins were not to be found in goitre-free villages. ${ }^{84}$ A Campbell contributed a study of goitre in animals in Nepal in $1835 ;{ }^{85}$ then a human case study in which he recommended Croton oil treatment, remarking casually that "the enormous expense of Iodine renders its general use, (in countries where goitre prevails to a great extent) quite out of the question."86 Economic problems with iodine treatment do not, however, seem to have been insuperable. Cost was mentioned at Tirhoot in the 1860s as a drawback to iodine use, ${ }^{87}$ yet Nottidge Charles Macnamara, also at Tirhoot and claiming that during three years "twenty-three thousand Goitre cases have been treated at the dispensary under my charge", noted that the biniodide of mercury ointment "is easily made, is very cheap, and a little of it goes a long way". ${ }^{88}$

Though cretinism figures only slightly in these early medical studies, it was not merely an "exotic Eastern" condition to the British physicians in India. There were wellestablished medical links between Britain and two countries with Alpine goitre areasFrance and Switzerland. Furthermore, apart from the goitre area known for "Derby Neck", ${ }^{89}$ there were a number of isolated "cretinous villages" in England. Hugh Norris in 1848 described a Somerset village, Chiselborough, where, apart from some obvious cretins, most of the population was goitrous and intellectually weak. ${ }^{90}$ Use of burnt sponge was known in Britain, not only as a folk remedy but in the scientific literature also. ${ }^{91}$

The next recorded treatment advance happened in the winter of 1854-55, when Captain Cunningham, of the 12th Irregular Cavalry, treated over 20,000 people with goitres, from a wide area around Segowlee in the Terai, using an iodine-bearing ointment plus blistering from solar exposure. He noted incidentally that "there are so many idiots about this part of the country only slightly affected with goitre, that it would be difficult to say whether idiotcy was actually induced by it, or the symptoms increased in those whose intellect was

$83 \mathrm{~J}$ McClelland, 'Observations on goître', Trans. med. Physical Soc., Calcutta, 1835, 7: 145-55. More detailed observations appeared in ibid., op. cit., note 81 above, pp. v-vi, 63-111.

84 Ibid., op. cit., note 81 above, p. 106.

85 A Campbell, 'Observations on the congenital goitre in animals, which occurs in Nipal', Trans. med. Physical Soc., Calcutta, 1835, 7: 1-8.

${ }^{86}$ Campbell, op. cit., note 63 above.

${ }^{87}$ Kenneth Norman MacDonald, 'Notes on some of the diseases most frequently met with among the natives of Tirhoot', Indian med. Gaz., 1866, 1: $323-4$

${ }^{88} \mathrm{~N}$ C Macnamara, 'Note on the use of biniodide of mercury', Indian Ann. med. Sci., 1862, 8 (15): 184-6, p. 184.

${ }^{89}$ See, e.g., Thomas Prosser, An account and method of cure of the bronchocele, or Derby neck, London, 1769.

\footnotetext{
${ }^{90}$ Hugh Norris, 'Notice of a remarkable disease, analogous to cretinism, existing in a small village in the West of England', Medical Times, 1848, 17: 257-8.

91 John C Lettsom, 'The histories of two cases of bronchocele', Mem. med. Soc. London, 1792, 3: 489-93. See also Timothy Lane, 'An account of two cases of a bronchocele', ibid., 1792, 1: 217-21, written in 1776 , referring back to 1764 . Lettsom indicates that burnt sponge began to be used by physicians after 1750. Bradford Wilmer, in Cases and remarks in surgery, London, Longman, 1779, pp. 233-54, gave details of medicines involving burnt sponge, the recipes of which had been a family secret in use more than twenty years earlier at Coventry (p. 250).
} 


\section{Miles}

naturally defective." 92 Major Holmes later calculated that by the spring of 1857 , some 60,000 cases of goitre had been treated. ${ }^{93}$ Perhaps he merely tripled Cunningham's estimate of cases seen during the first season; yet the large numbers involved, and remarkable success rate, were replicated in the $1860 \mathrm{~s} .{ }^{94} \mathrm{John}$ Whishaw gave bimonthly figures from Fyzabad, totalling 4,968 new patients treated for goitre during sixteen months, and noted that "Each goïtre is measured with a tape and callipers and the dimensions noted for the purpose of comparison." 95 Henry Greenhow in 1859 found cretinism "quite unknown throughout the Himalayan regions; and according to my own experience in Oude, it is equally unknown there. Out of my 300 cases of goitre, I only met with one individual who showed the least sign of weak intellect."96 A similar observation was made later by Ernest Waters, who examined the necks of 169 Bhutias in north-east Bengal. He found 75 per cent of them affected with goitre, but no cretins. ${ }^{97}$ Traill at Kumaon had earlier suggested that goitre "injures only the personal appearance, and not the bodily health or mental faculties of the subject"; 98 but many subsequent observers did find mental and/or physical problems in a significant proportion of goitre sufferers. Among them was McClelland, who thought that there was "no disease of which the people have greater dread, or from which they are more anxious to be relieved." 99

\section{Later Non-Medical Witnesses}

Writing of the same period as Greenhow, Assistant Commissioner MacMahon gave quite a different picture from the Punjab, where he "frequently visited Bajwat between 1856 and 1861. Nowhere in so small a space, not even in the worst valleys in Switzerland, have I seen so much goitre and cretinism." 100 At Hoshiarpur, Coldstream noted that "The condition sometimes reaches the degree of absolute imbecility, but generally stops far short of this ... I have on a previous occasion made an estimate that 5 to 10 per cent. of those afflicted with goitre will be probably found more or less imbecile. The affliction is much more common in the Trans-Beás Kangra district than it is here". ${ }^{101}$ The Settlement Commissioner, Kashmir and Jammu State, noted that 520 cases of goitre were treated in $1891-92,{ }^{102}$ and that certain villages were notorious for goitre and idiocy. ${ }^{103} \mathrm{~A}$ review of

\footnotetext{
92 Frederic J Mouat, 'Memorandum on the use of biniodide of mercury, in combination with the rays of the sun for the cure of goitre', Indian Ann. med. Sci., 1857, 4: 436-40, p. 439. Mouat, Inspector of Jails and Dispensaries, Bengal, communicated this work which mostly comprised letters from Major James G Holmes and Captain William R Cunningham. The latter do not seem to have had medical training.

93 Ibid., p. 437.

94 Macnamara, op. cit., note 88 above. N C Macnamara and A [sic] M Greenhow, 'On the treatment of goitre with the biniodide-of-mercury ointment', Ann. military naval Surg. trop. Med. Hyg., 1864, 1: 255-7. Macnamara (op. cit., note 88 above) emphasized care in preparing the ointment from pure, active materials.

$95 \mathrm{~J} \mathrm{C} \mathrm{Whishaw,} \mathrm{'The} \mathrm{treatment} \mathrm{of} \mathrm{goitre} \mathrm{by} \mathrm{the}$ biniodide-of-mercury ointment', Lancet, 1863, ii: 438 . Twenty years later, the method was still
}

"entirely successful" according to Albert A Gore, 'Acute goitre: its aetiology: thirty cases treated by the application of biniodide of mercury ointment', Indian med. Gaz., 1884, 19: 354-8, p. 357.

${ }^{96}$ Henry Martineau Greenhow, 'Observations on goitre, as seen in Oude', Indian Ann. med. Sci., 1859, 6 (11): 435-51, p. 449.

${ }^{97} \mathrm{E}$ E Waters, 'Notes on endemic goitre in northeast Bengal', Br. med. J., 1897, ii: 650-1.

98 Traill, op. cit., note 52 above, p. 215.

${ }_{99}$ M'Clelland, op. cit, note 81 above, p. 84 .

100 Colonel MacMahon's comment did not reach the medical literature. D C J Ibbetson quoted it in Report on the census of the Panjáb taken on the 17th of February 1881, Calcutta, 1883, vol. 1, p. 409. ${ }_{101}$ Gazetteer of the Hoshiarpur district 1883-4, Lahore, Punjab Government, [1884], p. 32.

102 Lawrence, op. cit., note 20 above, p. 232.

103 Ibid., pp. 34, 293, 460. 


\section{Goitre, Cretinism and Iodine in South Asia}

"infirmities" in the 1901 Census of India Report commented on the effects of cretinism, loosely understood, on the returns for insanity '(which included idiocy) and deafmutism. ${ }^{104}$ Later investigators systematically examined data from the censuses between 1881 and 1921 and the Imperial Gazetteers for goitre data. ${ }^{105}$ After studying this database, and making comparisons with Derbyshire experiences, the pathologist Hugh Stott continued to doubt the iodine deficiency theory, while recognizing wryly that to do so had become "almost a heresy in modern medicine". 106

In 1880, Francis Nottidge Macnamara published the first major collection of data drawing on district officers' reports as well as medical sources across the Himalayas and foothills. ${ }^{107}$ His hypothesis, connecting goitre with malaria, was not sustainable; yet the fact that he was pursuing it increases the retrospective value of his collection by reducing the likelihood of his having selected data favourable to some more tenable theory. Macnamara's work is too lengthy to be examined here, but shows that such data had been accumulated and examined across large areas of north India by 1880 , while doctors and others were treating many thousands of goitrous people annually. Macnamara noted the irregular association of cretinism and goitre. "In some places where goitre is excessively prevalent there is no cretinism; in other places the diseases prevail together. Cretinism shows itself at an earlier age than does goitre, and there is evidence of its being in some cases inherited."108 The "evidence" for its heritability seems to have been mainly data from Champaran, comparing children born to healthy, goitrous and cretinous parents. ${ }^{109}$ Macnamara noted the local belief that cretinism was hereditary and was much increased by consanguineous marriages. Clement Sconce, medical officer at Champaran, believed that cretinism was "congenital, that is, that children are born goitrous. . . . There is a village in Chumparun called Gayger Toleh (goitre village) where the disease is said to be almost universal." 110

The term "cretin", however, was used broadly, whether by medical or non-medical reporters, for idiocy of varied provenance; and sometimes it was used deliberately for particular socio-political ends. ${ }^{111}$ Further, Macnamara noted that, among 22,780 cases of goitre treated from 1868 to 1871 at dispensaries in Tirhoot, "there was but one idiot", and considered that these figures "disprove any association of goitre with cretinism and idiocy" at least at Tirhoot. ${ }^{112}$ It did not occur to him that only one idiot among 22,780 people was a remarkably low figure, even allowing for the likelihood of preferential mortality of severely disabled people. It is more plausible that idiots were seldom presented at dispensaries, whether they were goitrous, cretinous, or had any other sort of illness. If families took them anywhere, it would have been to shrines, as they still do today. Cretins were also liable to be enumerated as "deaf-mute" rather than "idiot", sometimes with justification. This probably happened in the Naga Hills, where deaf-

\footnotetext{
104 H H Risley and E A Gait, Census of India, 1901. Volume I. India. Part I. Report, Calcutta, 1903, pp. 131-6. See also Ibbetson, op. cit., note 100 above, pp. 408-11.

105 Stott, et al., op. cit., note 27 above.

$106 \mathrm{H}$ Stott, 'Distribution of simple goitre in Derbyshire', Indian med. Gaz., 1935, 70: 152-4, p. 152.

${ }^{107}$ F N Macnamara, Climate and medical topography in the relation to the disease-distribution
}

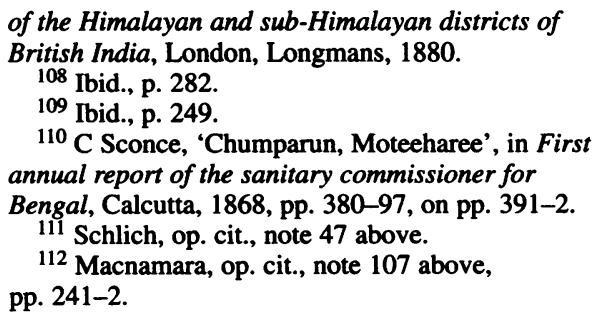




\section{Miles}

mutism was reported to occur among 49 per 10,000 males, as against 9 per 10,000 in Assam and 6 per 10,000 in India. ${ }^{113}$ Lewis O'Malley, better known as chronicler of the Indian Civil Service, stooped to note "deaf-mute idiots" at Champaran, and gave a rare comment on their place in the community: "It is a common sight to see them going out with village children to tend cattle, and sometimes deaf-mute idiots tend cattle alone."114 Not long after, the first formal effort in South Asia to educate "idiots" was begun by Silvia de la Place at the hill station of Kurseong, in 1918. ${ }^{115}$

In his collection of folk tales from the Upper Indus, the Rev. Charles Swynnerton included a goitre story. A fool saw a camel with a melon stuck in its throat, which its owner dislodged by giving the camel a great blow on the throat. The fool then pretended to be a doctor who could cure human goitre using a similar technique; which proved unsuccessful. ${ }^{116}$ This was not a great contribution to medical science; yet its attainment of folklore status indicates that the disease was commonplace, while no standard cure was known for it. Various later linguists and anthropologists mention goitre and cretinism in the Himalayas. ${ }^{117}$ Geoffrey Gorer, who lived with the Lepchas of Sikkim, reported that the ancestor-guardians of the Lepchas "all have huge goitres and it is from them that people know that big goitres are a sign of prosperity and a large harvest."118 John Staley, however, learnt in Kohistan of "dwarfs who take goitres from their own necks and throw them onto the necks of passers-by". ${ }^{119}$ Kunzang Choden also records a folktale of a malignant spirit with a goitre in Bhutan. ${ }^{120}$ These stories can be of value to health educators wishing to introduce the alternative pictures of medical science-which may sound as ridiculous to a rural audience as the folktales do to scientists. Rural villagers might more willingly accommodate the modern picture in their thinking if scientists take some interest in the rural conceptual worlds.

\section{An Indigenous Remedy}

Compartmentalization of knowledge featured in the very slow growth of awareness, among European scientists, that Indian bazaar druggists had stocked iodine-bearing remedies for goitre throughout the nineteenth century, and possibly earlier. Whitelaw Ainslie, in his substantial Materia Indica, noted in 1826 that sponge was "sometimes, though rarely, exposed for sale in the bazars of Lower India; brought from the Red Sea" and was recommended for treatment of bronchocele. ${ }^{121}$ More specifically, in Traill's list

113 B C Allen, Assam district gazetteers. Vol. IX. Naga Hills and Manipur, Calcutta, 1905, p. 37.

${ }^{114}$ L S S O'Malley, Bengal district gazetteers. Champaran, Calcutta, Bengal Secretariat, 1907, pp. $60-1$. M'Clelland, op. cit., note 81 above, pp. 43,90 , 108 , had noted "some mechanical skill" among goitrous and cretinous copper miners in a Kamaon village.

115 Annual report on European education in Bengal, for the year 1918-19, Calcutta, 1919, p. 5.

${ }_{116} \mathrm{C}$ Swynnerton, Folk tales from the Upper Indus, Islamabad, National Institute of Folk Heritage, reprinted 1978, originally Indian nights' entertainment; or folk tales from the Upper Indus, London, 1892, pp. 307-10.
117 G Gorer, Himalayan village, London, Michael Joseph, 1938, pp. 173-4, 236, 307, 371-2. Goitres had been reported 80 years earlier among the Lepchas, by Joseph D Hooker, Himalayan journals, London, John Murray, 1854, p. 134.

118 Gorer, op. cit, note 117 above, p. 236 , also p. 173.

119 J Staley, Words for my brother, Karachi, Oxford University Press, 1982, p. 169.

${ }^{120} \mathrm{~K}$ Choden, Folktales of Bhutan, Bangkok, White Lotus, 1993, pp. 115-19.

121 W Ainslie, Materia Indica, 2 vols, London, Longman, Rees, et al., 1826, vol. 1, p. 401. Ainslie mentioned sponge as one of many seaplant sources of iodine, vol. 1, p. 633 . 


\section{Goitre, Cretinism and lodine in South Asia}

of goitre remedies at Kumaon the most popular was "a simple sold in the bazar, under the name of "Gellur Patta"'. Reviewing external and internal nostrums, Traill found all "notoriously, without the slightest prospect of success in any but incipient cases." 122 The surgeon and botanist John Forbes Royle noted that "Gillur-ke-putta, or goitre leaf", which was "considered efficacious" in the Himalayan foothills for curing goitre, was probably a seaweed, with iodine as the active agent. ${ }^{123}$ The traveller Godfrey Thomas Vigne was familiar with regional medicines after several years of excursions in Central Asia and the Himalayas. Discussing goitre in Kashmir and Ladakh, he stated that "The use of burnt seaweed (which, I need not add, contains iodine) in the cure of goître, appears to have been long known to the Chinese; and I have myself purchased, I think it was at Ladak, a piece of common sea-weed, which had been, no doubt, brought there by the merchants trading between China and Turkistan."124

By 1847, Royle had identified the relevant seaweed as a species of Laminaria, and thought it came from the China seas. ${ }^{125}$ In the second edition of his Materia medica, Royle added the Caspian Sea or the Persian Gulf as possible sources. ${ }^{126}$ Ranjit Singh's colourful physician, John Martin Honigberger, not only knew of the seaweed Laminaria saccharina, but prescribed it in the 1830 s, attributing its success to the iodine content. He noted that its fronds were "officinal at Lahore and in Cashmere", and suggested possible origins in a salt lake of Tibet or the Caspian Sea. ${ }^{127}$ Writing for the India Office, Edward Waring noted that "gillur ka putta" was a non-officinal remedy, taken as an infusion. ${ }^{128}$ Finally in 1886 the seaweed achieved a positive mention in the Indian Medical Gazette when Jai Singh noted that "Galpatr ('leaves for the neck')" used at Chiniot in the Punjab were "vegetable leaves (Laminaica saccharina) for chewing", which were said to have a positive effect on goitre. ${ }^{129}$ The date or period when Laminaria saccharina was first used

122 Traill, op. cit., note 52 above, pp. 215-16.

$123 \mathrm{~J}$ Forbes Royle, Illustrations of the botany and other branches of the natural history of the Himalayan mountains and the flora of Cashmere, London, 1840, vol. 1, pt. II, pp. 441-2.

124 G T Vigne, Travels in Kashmir, Ladak, Iskardo, etc., 2 vols, London, Henry Colburn, 1842, vol. 1, p. 198. Surgeon General Charles A Gordon, An epitome of the reports of the medical officers to the Chinese Imperial Maritime Customs Service, from 1871 to 1882 , London, Baillière, Tindall and Cox, 1884, p. 232, notes chewing of the seaweed "Kwen-pu" to treat goitre in China.

${ }^{125}$ Royle, op. cit., note 123 above, pp. 40, 630-1.

$126 \mathrm{~J}$ Forbes Royle, A manual of materia medica and therapeutics, 2nd ed., London, Churchill, 1852, p. 691. Laminaria saccharina was identified with the iodine-rich "K' un Pu" listed by K Chimin Wong and Wu Lien-Teh, History of Chinese medicine, 2nd ed., Shanghai, National Quarantine Service, 1936, pp. 119-21, among Chinese seaweeds used for goitre treatment. Paul Unschuld, Medicine in China. A history of pharmaceutics, Berkeley, University of California Press, 1985, p. 356, identifies “K'un-pu" as Laminaria japonica Aresch. E H Schafer, The golden peaches of Samarkand, Berkeley, University of California Press, 1963, pp. 149, 190 and footnotes, identified a T"ang dynasty trade in "kompo" across Korea and China. Miyasita, op. cit., note 13 above, pp. 20-1, noted " $k$ 'un-pu" as a goitre remedy in Chinese formularies, written around $200 \mathrm{cE}$, also in the mid-seventh century, in 1482 and in 1556. Miyasita suggests that from the mid-sixteenth century "the diagnosis of goitre and wen became confused and the prescriptions for both diseases also became obscure" (p. 21).

$127 \mathrm{~J}$ M Honigberger, Thirty-five years in the East, London, Baillière, 1852, pp. 52-3, 297. J L Stewart, in Punjab plants, Lahore, Government Press, 1869, p. 269, quoted Honigberger, but favoured a China Seas origin for "gillar pattr", which he thought was "found in most Bazars".

128 E J Waring, Pharmacopoeia of India, London, W H Allen, 1868, pp. 260-1. Waring cited Cope, to whom the botanist Thomson had suggested an origin at "the mouth of the Amoor River or thereabouts", i.e. the Amurdarya which flows into the Aral Sea. H Cope, 'Remarks on a sea-weed called Gillur-kaputta; with a note thereon by Dr. T. Thomson', J. agri-hort. Soc. India, 1858, 10: 216-20.

${ }_{129}$ Jai Singh, 'Prevalence of goitre in Chiniot and in the villages about it', Indian med. Gaz., 1886, 21: 74-6. Singh was the first Indian to write specifically on goitre in the colonial medical journals; though 
in the Himalayas and northern India remains obscure. Writing from Amritsar, Henry Cope posed this question in 1858 and noted that "Tradition says it was first introduced about seventy years ago." 130 Possibly some eighteenth-century Kashmiri or Persian sources may yet shed light on this. "Galpar-ka-patta" [thus in both text and index] continues to appear in a 1986 reprint of Nadkarni's pharmacopoeia, as a remedy for "bronchocele". 131

\section{Experience Hard Won and Soon Lost}

Even amongst the British Indian medical literature, earlier material was liable to become inaccessible, or was simply unknown, to later researchers. Throughout the nineteenth century, various journals and medical societies were started for the better dissemination of medical advances, ${ }^{132}$ but rural medical officers were still often isolated from professional literature. Even in Calcutta, Ronald Ross complained that "to read up a subject thoroughly one must take furlough and go to London for it", ${ }^{133}$ as he himself had done in 1888-89 before starting his investigations into malaria. Referencing in published papers was poor and haphazard. The earlier goitre and iodine reports were in Indian journals with modest circulation, libraries stocking them were few, and medical indexing services were in their infancy. Shortly after his retirement from India, Joseph Fayrer found it worthwhile to reprint excerpts from Greenhow's and Frederic Mouat's papers, and to mention McClelland, Bramley and Campbell. ${ }^{134}$ Data and experience, not already cited above, continued to accumulate through the nineteenth century on various aspects of goitre across South Asia, from travellers, army surgeons, apothecaries and civil servants. ${ }^{135}$ Thus from Scott's innovation in 1825 to the turn of the century, South Asian goitre, cretinism and iodine treatment acquired a substantial basis of observation and documentation. Meanwhile goitre surgery had been "looked upon with disfavour in India" according to Harold Brown, addressing the Calcutta Medical Society in $1892 .{ }^{136}$ Brett's

useful comments had earlier been made by P A Minas, 'Report on the prevailing diseases in the Madhopore district', Indian med. Gaz., 1871, 6: $253-5$.

${ }^{130}$ Cope, op. cit., note 128 above, p. 219.

131 K M Nadkarni, Indian materia medica, revised by A M K Nadkarni, Bombay, Sangam, 1927, reprinted 1986, vol. 1, p. 724. Nadkarni suggested, improbably, that Laminaria saccharina was "found throughout India in salt lakes and deep seas".

132 See A Neelameghan, Development of medical societies and medical periodicals in India, 1780 to 1920, Calcutta, Oxford Book \& Stationery Co., 1963.

${ }^{133} \mathrm{R}$ Ross, 'The need for a medical library in India', Indian med. Gaz., 1898, 33: 199. The lack of a medical library contrasts with the development of natural history museums since 1802 , and early provisions for botanical knowledge, both of which held stronger commercial promise. See Andrew Grout, 'Possessing the earth: geological collections, information and education in India, 1800-1850', in: Nigel Crook (ed.), The transmission of knowledge in south Asia, Delhi, Oxford University Press, 1996, pp. 245-79; K N Matthew, 'Botany and its technologies in peninsular India in the eighteenth and nineteenth centuries', Indian J. Hist. Sci., 1982, 17 (2): 353-64.

134 Fayrer, op. cit., note 27 above.

135 See J W Bennett, Ceylon and its capabilities, London, Allen, 1843, p. 348. Henry Cayley, 'Notes on Ladak in 1867', Indian med. Gaz., 1868, 3: 3-5. J B Wilson, 'Some inquiries into the causes of goître and circumstances under which cretinism is developed', Med. Times Gaz., 1874, 2: 692-4.

H A Chatham Gray, 'Bronchocele in Baxa, Bhootan', Lancet, 1877, i: 937-8. W H Adley, Sanitary report of the Province of Assam for the year 1876, Simla, Government Central Branch Press, 1877, pp. 50, 64. T K Hall, 'Three cases of goitre', Indian med. Gaz., 1879, 14: 18-19. L Cameron, 'Contribution to the medical history of goitre', ibid., 1880, 15: 175-6. Calcutta Medical Society, ibid., 1880, 15: 250-1. George M Giles, 'Notes on endemic goitre; its aetiology and treatment', Indian med. J., 1886, 5: 467,515 .

${ }^{136}$ Calcutta Medical Society, 'The operative treatment of goitre, with cases', Indian med. Gaz., 1892, 27: $340-3$, p. 340. 


\section{Goitre, Cretinism and Iodine in South Asia}

textbook on surgery in India had described European goitre surgery more than fifty years earlier; ${ }^{137}$ but Greenhow thought that Indians would "never submit to undergo an operation for goitre". ${ }^{138}$ Towards the close of this period, some disappointment with iodine treatment was reported, and the President of the Calcutta Medical Society, K Chunder Bose, found that Brown's paper on surgery was the more needed "especially as the method of biniodide of mercury inunction, with arsenic and quinine internally, had been so extensively tried and found wanting." 139 The extent of this disappointment is not clear, since earlier in 1892 Upendra Nath Sen reported successful daily use of iodine for "at least half-a-dozen cases of goitre" in the previous two years at Mymensing. ${ }^{140}$

The extensive work of this earlier period has now almost entirely disappeared from view, for several reasons:

(1) Until Eugen Baumann found iodine in the thyroid in 1896, its known efficacy in goitre treatment had no clear explanation. ${ }^{141}$ All prior work had a speculative foundation. Many painstaking efforts to analyse water, record temperature and compare elevations, later seemed like gropings in the dark. The French mining engineer Jean-Baptiste Boussingault's account of experiences in South America, and his recommendation of naturally iodized salt, which had been used successfully in Antioquia, Colombia, for nearly two centuries, made little impact. ${ }^{142}$ When Gaspard Adolphe Chatin, from 1849 on, accumulated meticulous environmental measurements across Europe and deduced that iodine deficiency was the main cause of goitre, ${ }^{143}$ his work fell flat. A committee of the French Académie des Sciences reviewed Chatin's presentations, but found his evidence inconclusive, given the problems they perceived in measuring accurately very small amounts of iodine. ${ }^{144}$ There was also a conceptual problem. David Marine noted that, half a century after Chatin, "between 1905 and 1910 Lenhart and I frequently heard the criticism that it was difficult to conceive of a deficiency or absence of something causing something." ${ }^{45}$ Recently Bernardino Fantini has traced how the rise of the germ theory of disease, while shedding great light in other directions, served to obscure the deficiency basis of goitre. ${ }^{146}$

${ }^{137}$ Brett, op. cit., note 82 above, pp. 118-20.

138 Greenhow, op. cit., note 96 above, p. 451.

139 Calcutta Medical Society, op. cit., note 136 above, p. 343. Goitre surgery in India was risky. Surgeon H Smith, 'The work of the Jullundur Civil Hospital in 1906', Indian med. Gaz., 1907, 42: 326-8, excised many goitres but deplored the patients' "peculiar liability to not only dying on the table, but within half an hour after leaving it from the effects of chloroform".

${ }^{140}$ Upendra Nath Sen, 'Goitre or bronchocele and its curative treatment', Indian med. Gaz., 1892, 27: 75.

${ }^{141}$ E Baumann, 'Über das normale Vorkommen von Jod in Thierkörper', Hoppe-Seyler's Z. physiol. Chem., 1896, 21: 319-30.

142 Jean-Baptiste Boussingault, 'Recherches sur la cause qui produit le goître dans les Cordilières de la Nouvelle-Grenade', Ann. Chim. Phys., 1831, 48: 41-69.

${ }^{143}$ See, e.g., G A Chatin, 'Recherche de l'iode dans l'air, les eaux, le sol et les produits alimentaires des Alpes de la France et du Piémont', $C$. r. hebd. Séanc. Acad. Sci., (Paris), 1852, 34: 51-4.

144 Thenard, Magendie, Dumas, Gaudichard, de Beaumont, Pouillet, Regnault and Bussy, 'Rapport sur les travaux de M. Chatin', ibid., 1852, 35:

505-17, on p. 511. Chatin later explained how he overcame such problems: 'Des causes d'insuccès dans la recherche de minimes quantités d'iode', ibid., 1876, 82: 128-32.

145 D Marine, 'Endemic goitre: a problem in preventive medicine', Ann. intern. Med., 1954, 41: 875-86, p. $880 \mathrm{fn}$.

146 B Fantini, 'La révolution pastorienne et les théories sur l'étiologie du goitre et du crétinisme', Gesnerus, 1992, 49: 21-38. Editorial comment on 'The aetiology of goitre', Indian med. Gaz., 1900, 35: 107-8, noted Baumann's work as possible evidence that iodine caused goitre, but thought this was contradicted by the existence of "valleys where the water is rich in iodine, yet [sic] goitre does not occur" (p. 107). 
(2) The history of goitre has been neglected, compared with that of other global afflictions. Even bibliography has been weak. Merke's many, detailed and multilingual references are dispersed throughout his tome, rather than being collated at the end. ${ }^{147} \mathrm{Sir}$ Charles Harington's bibliography is extensive, but he was not primarily writing history. ${ }^{148}$ Parallel with Merke's labours, goitre history was pursued internationally between 1945 and 1975 by the American biochemist Isidor Greenwald, who aimed to disprove the antiquity of goitre and the iodine deficiency theory, in favour of an infection hypothesis. Though unsuccessful, he found much useful historical data. Greenwald set rigorous standards for the scrutiny of evidence, pointing out the frequent confusion of goitres with scrofulous lymph glands and the vagueness of terminology in many historical accounts. ${ }^{149}$ Yet his sole essay in South Asia was a glance at Ceylon, ${ }^{150}$ and he was clearly unaware of the wealth of Indian goitre literature. As early as 1883, Norman Chevers, the veteran of forensic medicine in India, was mourning the loss of invaluable medico-topographical district surveys and histories, prepared in India on Government orders from 1835 onwards. Of these, he complained, only a few had "escaped until now the ravages of the white ants." 151 Since then, further ravages have occurred. Older Indian books and journals are now very scarce. The main modern international bibliography, ${ }^{152}$ lists nineteenthcentury work by only McClelland, Fayrer and Francis Macnamara for India, and Bramley for Nepal, giving an impression that little had been done in South Asia.

(3) McCarrison, who dominated Indian goitre studies for thirty years, made little direct reference to earlier Indian work, so his own work appears as the natural beginning. ${ }^{153} \mathrm{His}$ broad experimental involvement with nutritional studies and deficiency diseases, together with his and his colleagues' studies on iodine in soil, water and foodstuffs, ${ }^{154}$ kept raising problems for the simple iodine deficiency theory and allowed some place to infective agents. McCarrison's results tended to cast doubt on orthodox views, and to reinforce the complexity of the goitre-cretinism-iodine picture. This was good science; but "history" rather prefers the solver of problems to the poser of difficulties.

\footnotetext{
${ }^{147}$ Merke, op. cit., note 28 above.

148 C R Harington, The thyroid gland, London, Oxford University Press, 1933, pp. 196-218.

${ }^{149}$ See, e.g., I Greenwald, 'The early history of goiter in the Americas, in New Zealand, and in England', Bull. Hist. Med., 1945, 17: 229-68.

${ }^{150} \mathrm{Idem}$, 'Some notes on the history of goitre in Ceylon', Ceylon med. J., 1953, 2: 140-1.

Considering Greenwald's vigorous marshalling of other evidence, it is odd that he made little use of McCarrison's Asian work. Greenwald's papers are archived at the Frederick L Ehrman Medical Library, New York University School of Medicine.

${ }^{151} \mathrm{~N}$ Chevers, 'Medico-topographical health histories for districts and towns', Trans. Epidemiol. Soc. Lond., 1883, 3: 1-13, p. 3.

152 Endemic goitre. Select bibliography on world distribution, 2nd ed., London, Chilean Iodine Educational Bureau, 1960. See also F C Kelly and W W Sneddon, 'Prevalence and geographical distribution of endemic goiter', in Endemic goiter,
}

Geneva, World Health Organisation, 1960, pp. 27-233. A useful earlier list is given by August Hirsch, Handbook of geographical and historical pathology, 3 vols, transl. by C Creighton, London, New Sydenham Society, 1883-86, vol. 2, pp. 145-7.

${ }^{153} \mathrm{R}$ McCarrison, 'The distribution of goitre in India', Indian J. med. Res., 1915, 2: 778-90, on p. 778 mentioned the collation of many reports, but cited (p.782) only Macnamara, 1880, note 107 above. The risk of useful information disappearing surfaced in McCarrison's own experience. In addition to goitre and cretinism, he made notes on lathyrism in Gilgit, which he rediscovered only nineteen years later: idem, 'A note on lathyrism in the Gilgit Agency', ibid., 1926, 14: 379-81.

154 See, e.g., R McCarrison, C Newcomb, $B$ Viswanath and $R$ V Norris, 'The relation of endemic goitre to the iodine-content of soil and drinking water', Indian J. med. Res., 1927, 15: 207-46; M Patnaik, 'The iodine-content of Indian food-stuffs', ibid., 1934, 22: 249-62. 


\section{Goitre, Cretinism and Iodine in South Asia}

(4) Terminology was poorly defined in the earlier papers. There was no standardized scale for describing goitre size. Thus McCarrison noted that a sudden nine-fold increase in goitre incidence recorded at Lawrence Military Asylum (1905-1907) arose because a new medical officer based his diagnosis on palpation rather than visual observation. Recorded incidence plummeted when he was posted elsewhere. ${ }^{155}$ The term "cretin" was used loosely. Among the authors in India cited above, Sub Assistant Surgeon P A Minas was exceptional in providing a careful description of his cretins in Madhopore District. ${ }^{156}$ Monte Greer recently noted the reluctance of the medical profession to give up well-worn terms such as "bronchocele" and "thyroid extract", long after they were known to be inaccurate. ${ }^{157}$

The disappearance of knowledge is regrettable for practical rather than sentimental reasons. While many of the working hypotheses of earlier observers have been superseded, their work remains useful as medical ethnography, and for estimating possible epidemiological shifts. Some facts that puzzled them, for example, the reasons for one village being smitten while the next was spared, remain puzzling today. ${ }^{158}$

From the 1830s to the 1900 s, dispensaries were opened across British India, and efforts at rural health outreach were pioneered in the Punjab. ${ }^{159}$ Official records show, with detail, that by the close of the century nearly 2,500 civil hospitals and rural dispensaries were treating more than 20 million Indian outpatients per year. ${ }^{160}$ In a reaction to earlier, uncritical accounts of the Indian Medical Service, it has been fashionable to portray these developments as merely a tightening of imperial control over India, or to deny that any medical efforts were made for the mass of the population. This fashion has begun to yield to studies balanced by many other factors. ${ }^{161}$ It is unlikely that the records were sheer fiction, or that 20 million outpatients were an incidental spin-off of deep-laid harmful aims. Speculation about motives, a century later, cannot, of course, be proved or disproved. From evidence in the mass of reports written from the mid-nineteenth century onwards by doctors and district officers, and the diligence with which they collected and analysed data much beyond their official duties, it is not unreasonable to think that many were keenly interested in controlling disease and promoting health. The political and

$155 \mathrm{R}$ McCarrison, 'An enquiry into the causation of goitre at the Lawrence Military Asylum,

Sanawar', Indian J. med. Res., 1914, 1: 536-88, pp. 547-8.

${ }^{156}$ Minas, op. cit., note 129 above, pp. $253-4$, cited as definition "diminutive stature, flattened and large head, with flat nose, thick lips, short and curved legs; either deaf, dumb, or blind, vacant expression of the countenance, and void of intelligence".

157 M A Greer, 'Historical role of endemic goiter in elucidating the importance of iodine nutrition', Endocrinol. Exp., 1986, 20: 9-16, pp. 10, 12.

Bramley, op. cit., note 3 above, gave the alternatives "bronchocele or goitre" in 1833. Ayurvedic writers have kept "bronchocele" alive to the present (see, e.g., Nadkarni, op. cit., note 131 above, vol. 1, p. 724; Sen Gupta, op. cit., note 18 above, vol. 2, pp. 536-9).

${ }^{158}$ Clark T Sawin, 'Goiter', in K F Kiple (ed.),
The Cambridge world history of human disease, Cambridge University Press, 1993, pp. 750-6. Sawin notes the ongoing scientific task of "teasing out several probable factors in addition to iodine deficiency that can produce endemic goitre" (p. 754), as well as the geopolitical challenge of prophylaxis.

159 John C Hume, 'Rival traditions: western medicine and yūnān-i tịbb in the Punjab,

1849-1889', Bull. Hist. Med., 1977, 51: 214-31.

160 Report on sanitary measures in India in 1899-1900, vol. 33, Command paper 844, London, HMSO, 1901, p. 27.

${ }^{161}$ Mark Harrison, Public health in British India: Anglo-Indian preventive medicine, 1859-1914, Cambridge University Press, 1994, for example, notes the "varied and often conflicting viewpoints of colonial administrators and medical officers; and the importance of practical constraints, such as local revenues" (p. 2). 


\section{Miles}

military authorities clearly considered that such aims and achievements helped to justify the rule of 300 million indigenous people by a few thousand foreigners. ${ }^{162}$ Furthermore, goitre and cretinism posed little personal threat to British officers or their families, by comparison with diseases such as cholera and malaria. If a motive for British goitre research in South Asia must be found, other than professional competence or humanitarian concern, it might lie in sheer scientific curiosity. Goitre, and its relations with cretinism and with iodine, was an ongoing puzzle in which pieces of contrary evidence kept reappearing to challenge theory.

Whatever may have been the motives of Bramley, McClelland, Cunningham, Macnamara and others, it is easy to imagine their amazement if they could revisit South Asia today; but harder to explain why, with the urban development and advanced technology and mass communication media, more than a century after their pioneering work, goitre and cretinism continue to be major health problems. A seminar on iodine deficiency in Pakistan was reported to have been "taken aback by the fact that the disease first surveyed 80 years ago has continued to afflict the people despite the very simple remedy." 163 The lack of progress would have struck them all the more forcibly had they been aware that the remedy was in use in South Asia eighty years before McCarrison's surveys.

\section{Answering to the Past}

Underlying reasons for this failure may connect some of the earlier experiences won and lost. Simple, universal remedies were and are seductive. Iodine, once isolated, was tried enthusiastically and injudiciously for all manner of ailments, provoking vigorous condemnation when overdosing problems surfaced. A century later, David Marine and $O$ P Kimball's comment, that "simple goiter is probably the easiest of all known diseases to prevent", ${ }^{164}$ was willingly misinterpreted as "goitre is easy to prevent"- on a worldwide basis. In practice, it did not prove easy, as Marine acknowledged after forty years of effort. ${ }^{165}$ The simple technical solution (i.e. iodine prophylaxis via dietary supplement) to what was perceived as a straightforward technical problem, made substantial progress in ideal conditions. It was easily applied to docile populations who could be monitored daily, such as laboratory mice or the schoolgirls at Akron, Ohio, with whom Marine and Kimball worked. It was sensible to start with the easiest groups. To extrapolate directly from Akron schoolgirls to Himalayan tribespeople was over-optimistic. In fact, after the beginnings of school medical inspection in 1909, Major Webb at Simla and McCarrison at Sanawar succeeded in goitre control among schoolchildren, reducing the incidence to around 2 per

\footnotetext{
162 See, e.g., General Sir Neville Chamberlain, letter to Dr David Boyes Smith, quoted in the editorial, 'The political value of the Indian Medical Service', Indian med. Gaz., 1887, 22: 333-4. Major Holmes, in Mouat, note 92 above, p. 438, writing while "patients are pouring into the compound", argued for an extension of medical aid on humanitarian grounds; then "setting humanity aside", noted that it would pay the Government to get these people cured.
}

\footnotetext{
163 Ikramul Haq, 'Goitre menace. Simple remedy eludes authorities', Pakistan Times, 8 April 1985.

${ }^{164}$ D Marine and O P Kimball, 'The prevention of simple goiter in man', J. Lab. clin. Med., 1917, 3: 40-8. O P Kimball and D Marine, 'The prevention of simple goiter in man. Second paper,' Arch. intern. Med., 1918, 22: 41-4, p. 41.

165 Marine, op. cit., note 145 above, p. 884.
} 
cent, similar to that in non-endemic areas. ${ }^{166}$ Yet those local efforts, requiring neither fancy equipment nor foreign exchange but merely vigilance and attention to detail, were not extended even to schools across South Asia, let alone to remoter areas.

The ideal solution might appear to be an entirely passive "technical fix" prepared by pure scientists in spotless laboratories then sprayed from a great height upon the obstructive, incalculable, unhygienic mass of humanity. Alternatively, Thomas Schlich has traced the preference of pioneering surgeons for an organ-centred view of cretinism, avoiding any engagement with messy and intractable social problems as suggested by some earlier physicians. ${ }^{167}$ In practice, few preventive measures can be performed without involvement at local levels. Grand central schemes for health engineering need to be modified in the field to accommodate the conceptual world and customs of rugged, traditional thinkers living in remote parts, whose way of life and physiology has not been observed and recorded, or at least not recently; or perhaps recorded but lost in dusty library stacks. Marine noted that the obstacles to extending goitre prevention arose mainly from three sources: “(1) economic, (2) political, and (3) social”, all of which were "at present beyond the authority of a Public Health Service." 168

Throughout the nineteenth century, hundreds of expatriate physicians and district officers in Upper India experimented with iodine compounds and recorded their experiences; while thousands of Indian village empiricists chewed iodine-bearing seaweed, or drank its infusions. Somehow, the experience of the latter received barely a footnote in the records of the former. Only S Manuel, in a non-medical journal in 1885, placed tincture of iodine, and iodine from "gillar pattar", on an equal footing as remedies. ${ }^{169}$ The gap between these alternative conceptual worlds remains to be bridged. Remote populations have still to be convinced that the liquid which urban professionals want to inject into their babies, smear on their salt, or lower into their water supply will not reduce their independence, interfere with their sex lives, or annoy the spirits of their ancestors. Investigators at Champaran learnt that people preferred their usual fine white salt, non-iodized and at lower cost, to the "large muddy crystals of iodized salt". Further, "some villagers actually believed that the 'muddy salt' was responsible for leprosy!"170 Why did the planners "actually believe" that villagers would adopt something costlier and less attractive, on the advice of a humble, poorly-paid health worker? ${ }^{171}$

To be effective, persuasion may need to be applied skilfully, in person, by someone with good credibility, to groups of a hundred or less people; and reapplied, again in person,

\footnotetext{
$166 \mathrm{~J} \mathrm{R}$ D Webb, 'The medical inspection of school children at Simla', in Some experiments in Indian education, Calcutta, Bureau of Education, India, 1927, pp. 77-84. McCarrison, op. cit., note 155 above. Also R McCarrison, 'An experiment in goitre prevention', Br. med. J., 1927, i: 94-5. Success at Sanawar arose from a new bacteriologically pure water supply, even though this contained less iodine than the previous impure supply.

${ }_{167}$ Schlich, op. cit., note 47 above, pp. 440-1.

168 Marine, op. cit., note 145 above, p. 884. For comparison, the international tensions between technical and structural solutions in the deficiency disease of beriberi (another field where McCarrison was influential) are analysed by Anne Hardy,
}

'Beriberi, vitamin B1 and world food policy', Med. Hist., 1995, 39: 61-77. Technical quick fixes retain some appeal, but the broader, social and structural solutions have slowly become the official wisdom.

${ }^{169}$ S Manuel, Note No. 408, Panjab Notes \& Queries, vol. 2, Jan. 1885, No. 16. See also Notes Nos 226 and 301, ibid., vol. 1, Dec. 1883, No. 3. ${ }^{170}$ The national goitre, op. cit., note 7 above, p. 46.

${ }^{171}$ Boussingault, op. cit., note 142 above, p. 55, learnt that among the people of Antioquia efforts were sometimes made to render their naturally iodized salt more palatable by "purifying" it; but this soon resulted in goitres appearing. 


\section{Miles}

sometimes with subtle differences, to the next group living ten miles away and speaking a different dialect, and so on across populations totalling millions. A few of the wicked old colonial surveyors and medical officers understood this. If they wished to convince hill people, they called for horses or donned their walking boots. ${ }^{172}$ For example, the existence of some beneficial springs, whose water could cure goitre, was known locally; but this knowledge was hardly collated and acknowledged until McCarrison did so. ${ }^{173}$ To suggest to rural folk that they too could have the benefit of a "lucky well" (i.e. one where iodine was added, rather than natural) might have been a better stratagem than to try dosing them regardless of their perceptions. Even today, the introduction of iodized salt may need to be effected in person, rather than by remote media. S R Mazta and S K Ahelluwalia, recently discussing India's programme to control iodine deficiency disorders, noted that 20 per cent of their Himalayan people have no access to radio, and the same percentage are still using non-iodized salt. ${ }^{174}$

If the masses learn slowly, so do governments. In 1964, Pakistani researchers were celebrating the sophisticated tool of radioactive iodine, which had become "indispensable in the investigation of goitre."175 Fourteen years later, the Government of Pakistan reluctantly began facing the less glamorous yet equally indispensable need at the community level, when a report outlined the technical and sociological problems of salt iodization. ${ }^{176} \mathrm{~A}$ further fourteen years on, the educational problems remained hardly touched: "at present iodized salt slowly finds its way to the project area. Major challenges lie ahead, namely to increase the production of iodized salt and to develop an appropriate Information, Education and Communication strategy to reach and convince the communities to use iodized salt instead of rock salt." 177 Neighbouring Afghanistan, where the entire 20 million population is at risk of iodine deficiency, is only in the 1990s taking its first steps towards iodine prophylaxis. ${ }^{178}$ Goitre and cretinism pose no more of a threat to urban planners and politicians now than they did to the colonial powers a hundred years earlier; so protective measures for distant hillbillies hardly appear as an issue of national urgency. ${ }^{179}$

\footnotetext{
172 David Scott, an overweight man with heart problems, put himself in a harness by which a pair of mountaineers could help haul his bulk up the steep tracks between villages: White, op. cit., note 61 above, p. 33. O'Malley, op. cit., note 52 above, p. $192-3$, remarked that horse riding was still, in the 1930s, a compulsory subject which must be passed by probationers before entry to the Indian Civil Service.

${ }^{173} \mathrm{R}$ McCarrison, 'The distribution of goitre in India', Indian J. med. Res., 1915, 2: 778-90, pp. 788-9.

${ }^{174}$ S R Mazta and S K Ahelluwalia, 'Literacy campaign and health education go hand in hand', Wld Hlth Forum, 1995, 16: 184-5. See also Dorothy S Mull, Jon W Anderson and J Dennis Mull, 'Cow dung, rock salt, and medical innovation in the Hindu Kush of Pakistan', Soc. Sci. Med., 1990, 30: 675-91, who emphasize the need for a "trusted messenger" (pp. 688-9).
}

${ }^{175}$ Rafiq A Khan and Ali Jumshyd, 'Goitre in Karachi studied with radioactive iodine', J. Pakistan med. Ass., 1964, 14 (1): 3-8.

176 Sirajul Haq Mahmud, A H Maan and Habib Ullah, Goitre in Pakistan, Islamabad, Government of Pakistan, 1978, p. 16.

177 Situation analysis of children and women in Pakistan, Islamabad, UNICEF and Government of Pakistan, 1992, p. 69.

${ }^{178}$ Faizullah Kakar and A Verster, 'Iodine deficiency in Afghanistan', Wld Hlth Forum, 1996, 17: 209.

${ }^{179}$ India's Goitre Control Programme, for example, was characterized as "always a halfhearted, weak, highly fragmented and compartmentalized operation with no unified command", in: The national goitre, note 7 above, pp. 10-11. 


\section{Goitre, Cretinism and Iodine in South Asia}

Reviewing prophylactic programmes globally, Claude Thilly and Basil Hetzel concluded that "technological considerations, although basic, do not determine whether an iodization program succeeds." 180 Yet even the technical details can be difficult enough. ${ }^{181}$ There are substantial problems in distributing iodine with salt or injections to remote areas with minimal infrastructure. To do so effectively, along with the other "goods" of a modern, public health service, urban planners need basic ethnographic information, a carefully targeted campaign, political will shown in the availability of financial resources, and involvement of the target groups in their own ongoing health and welfare. ${ }^{182}$ At the end of all this effort, there will be nothing visible, no monument, no big building, certainly no gratitude from the rural people; merely a healthier population and some papers in medical journals. Furthermore, there is no end to the efforts required, as western countries have learnt painfully in recent outbreaks of diseases once practically eradicated. Even in modern Switzerland, iodine supply is "now sufficient, but not overly so." 183 A change in international trade regulations, allowing import of cheaper, non-iodized salt, could upset the fine balance. The 5 to 10 per cent of Swiss school-children still having slight goitres could then be at risk of clinically significant levels-as happened when India began importing non-iodized salt in $1978 .^{184}$

\section{Conclusion}

A socio-historical perspective reveals challenging realities behind the highlights of urban scientific discovery. Progress in rural preventive health measures, especially for conditions posing minimal threat to urban planners or their children, takes place slowly, with many plateaux and unexpected dips, and only after unremitting efforts by an alliance of advocates, scientists, district officers and local leaders. The "technical fix" of iodine compounds for goitre and cretinism, known in Asia as a folk remedy for over two millennia before its scientific elucidation, took a further century to develop in a conceptual world far removed from the rural South Asian masses. To apply the result effectively to those masses requires its transfer and re-adoption into their conceptual worlds, with credibility generated by personal contact with respected figures. For this process, a review of historical sources provides pointers, reiterates some unsolved questions, and cautions against simplistic thinking.

\footnotetext{
${ }^{180} \mathrm{C}$ H Thilly and Basil S Hetzel, 'An assessment of prophylactic programs: social, political, cultural and economic issues', in John B Stanbury and Basil S Hetzel (eds), Endemic goiter and endemic cretinism, New York, Wiley, 1980, pp. 475-90, on p. 484.

181 N Kochupillai, V Ramalingaswami and J B Stanbury, 'Southeast Asia', ibid., pp. 101-21, on pp. 106, 111-12; also Stewart, note 74 above, p. 1509 .

182 With no such planning, dried seaweed travelled long, difficult routes, whether from coastal China to remote parts of nineteenth-century Ladakh or from the Aral or Caspian Seas to the Punjab and Sind. Presumably there was strong market motivation. The suggestion that "gillur-ke-putha" was a "favorite remedy" for syphilitic eruptions may have generated demands more urgent than those of goitre (James A
}

Murray, The plants and drugs of Sind, London, Richardson, 1881, p. 3). Oddly, however, very little traffic in the seaweed was reported at Amritsar by Cope, op. cit., note 128 above, p. 218.

${ }^{83}$ Hans Bürgi, Zeno Supersaxo and Beat Selz, 'Iodine deficiency diseases in Switzerland one hundred years after Theodor Kocher's survey', Acta endocr., Copenh., 1990, 123: 577-90, p. 587. See also B S Hetzel, 'Elimination of mental defect due to iodine deficiency by the year 2000', Int. J. Disabil., Dev. Educ., 1993, 40: 83-93.

184 National goitre, op. cit, note 7 above, pp. 37-8. An editorial in Daily Star of Bangladesh, 26 Jan. 1996 , noted that "A kilogram of non-iodised salt sells at Tk eight as against Tk 12 for the same amount of iodide salt". 